Obere Extremität 2015 - 10:252-257

DOI 10.1007/s11678-015-0314-4

Received: 25 February 2015

Accepted: 9 April 2015

Published online: 11 May 2015

(c) The Author(s) 2015. This article is published

with open access at Springerlink.com

Andrzej Zyluk · Agnieszka Mazur

Department of General and Hand Surgery, Pomeranian Medical University in Szczecin, Szczecin, Poland

\title{
Statistical and histological analysis of tumors of the upper extremity
}

mentioned [1-3]. Malignant tumors are relatively rare. The specific appearance and fast growth of the lesion may raise suspicion as to its malignant character.

Treatment of tumors in the hand is mostly surgical and consists in complete (radical) excision, as their character is not known preoperatively. It is usually performed in the operating theater, with the patient under adequate anesthesia, and in a bloodless operative field. All resected tumors are routinely sent for histological examination. Recurrences are not uncommon and are dependent on the character of the lesion, completeness of resection, and-to a certain degree-its localization. Removal of tumors arising from specific tissues, i.e., nerves, vessels, or bones, may require sophisticated techniques of reconstruction to avoid compromise of the hand function. In the case of malignant tumors that are preoperatively considered benign, secondary surgery is usu- ally necessary (radicalization of the operation), followed by chemoradiotherapy.

The authors' institution is the primary center of hand surgery in a part of the country having a population of about 4 million inhabitants, in which the vast majority of hand tumors are treated. The objective of this retrospective study was to investigate the prevalence, character, and demographic characteristics of all hand tumors operated on in 2013 and 2014.

\section{Patients and methods}

The patients treated at our institution were mostly referred to us from surgical or family doctors' outpatient clinics. Patients were included in this study if they met the following criteria: aged 18 years or older, with any soft tissue or bony tumor of the upper extremity, and a histological examination of the excised tumor being available. Exclusion criteria included suspected ganglion cyst, foreign body, arthri-

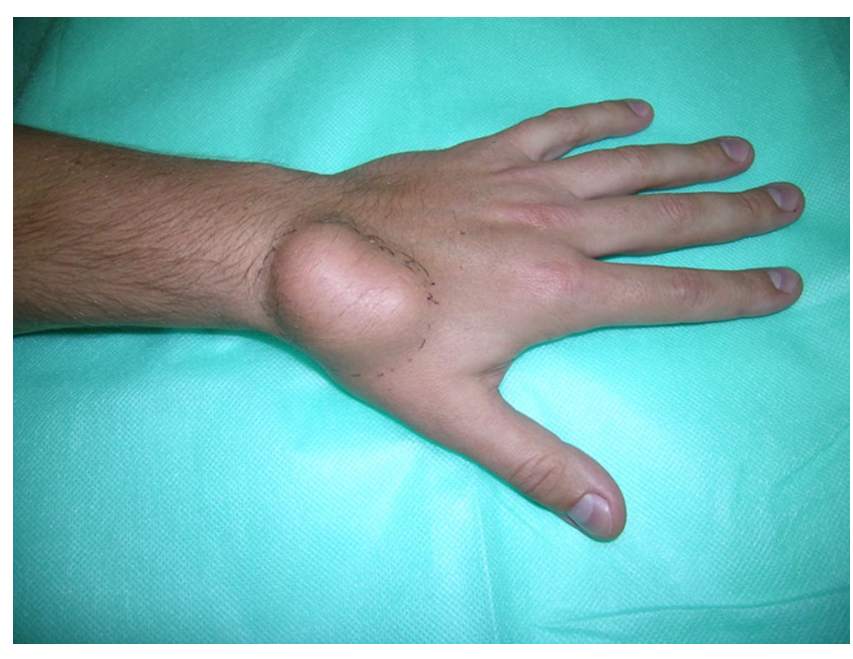

Fig. $1 \Delta$ Lipoma on the dorsum of the hand

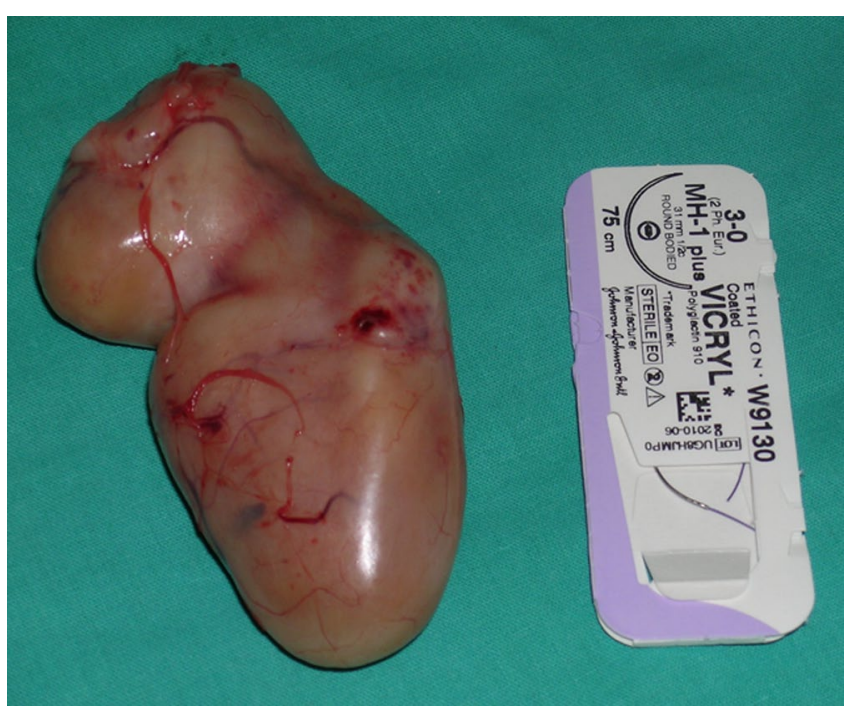

Fig. $2 \Delta$ View of a resected lipoma 
Table 1 Histological categories of tumors of the upper extremity

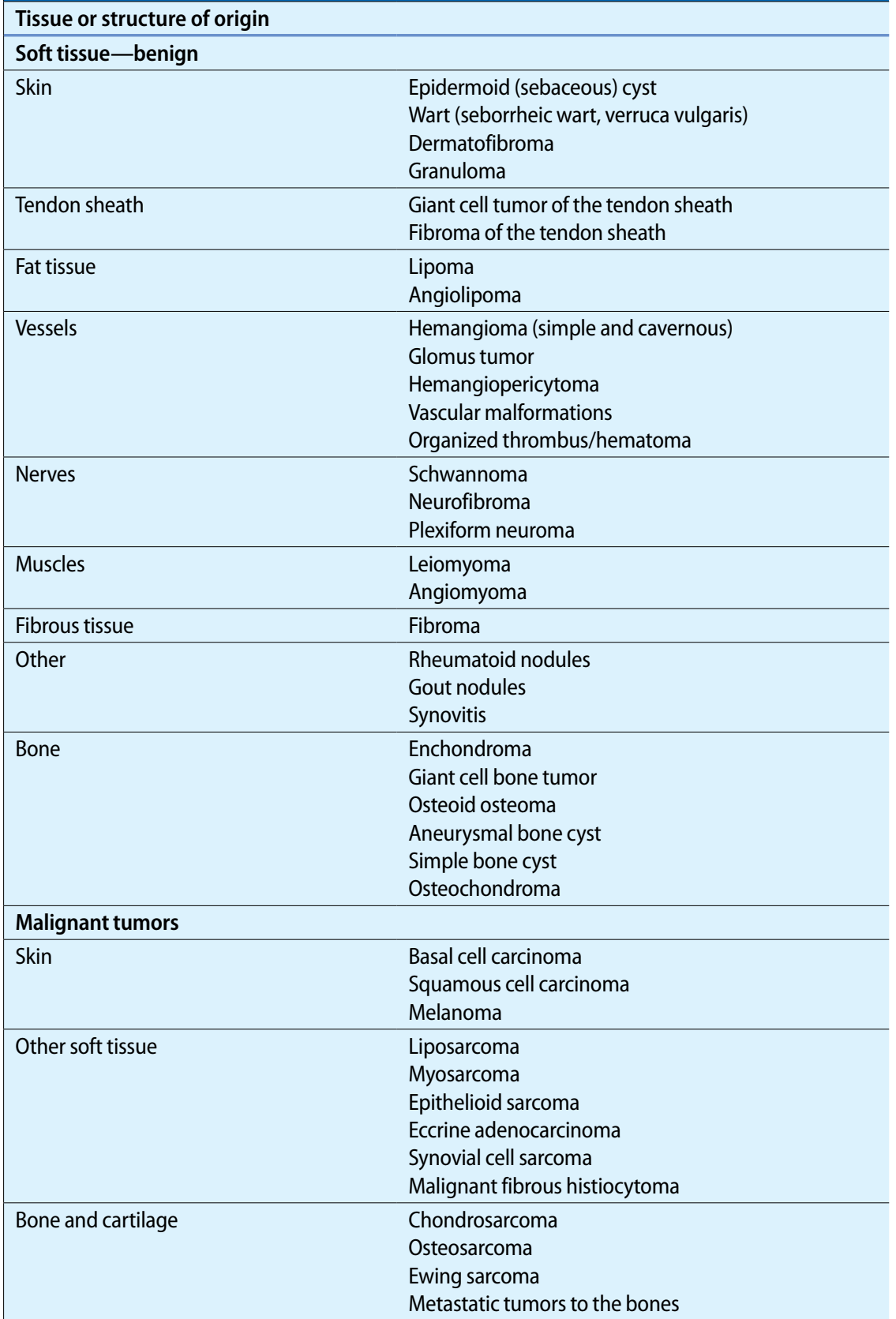

tis deformity, or osteophyte and high suspicion of malignant tumor (skin carcinoma, melanoma). In all, 246 patients, $74 \%$ of a total of 334 who were operated on for upper extremity tumors in 2014 year, met the inclusion criteria. Histological examination of the tumors was performed in the Department of Pathology at the Pomeranian Medical University in Szczecin. The study was retrospective and the following data were analyzed from the institutional database: age and sex of the patients, tumor location, X-ray examination (if per-

\begin{tabular}{|c|c|c|}
\hline Localization & Number of cases & $\%$ \\
\hline Digits & 119 & 48 \\
\hline Wrist & 49 & 20 \\
\hline Metacarpus & 40 & 16 \\
\hline Forearm & 25 & 10 \\
\hline Arm & 13 & 6 \\
\hline
\end{tabular}

sions were localized in the digits, followed by the wrist, metacarpus, and more proximal parts of the limb. The most often-occurring lesion type was giant cell tumor of the tendon sheath, followed by lipoma, epidermal cyst, enchondroma, and hemangioma (• Table 3). Soft tissue swellings were much more common than bony lesions (94 vs. $6 \%$ ).

\section{Location of tumors}

Giant cell tumors of the tendon sheath $(n=58)$ were localized most commonly on the dorsal $(n=25,43 \%)$ or palmar side of the digits $(n=17,29 \%)$, followed by the wrist $(n=9,16 \%)$ and the palmar metacarpus $(n=7,12 \%)$. Lipomas $(n=40)$ were more frequently seen in the forearm and $\operatorname{arm}(n=29,73 \%)$ than in the hand or wrist ( $n=11,27 \%)$. Two tumors were located deep in the thenar muscles and one in the deep palmar space. Of the epidermoid cysts $(n=23)$, the majority was seen in the skin of the dorsal aspect of the digits and metacarpus $(n=15)$, and the remaining eight in the wrist and forearm. Enchondromas $(n=16)$ were most frequently seen in the digits, in the proximal $(n=9)$, middle $(n=5)$, and distal phalanges $(n=2)$. Most of them involved the ring and little fingers $(n=10)$. Hemangiomas were located mostly on the palmar side of the fingers $(n=8)$, in the wrist $(n=3)$, forearm $(n=2)$, and on the palm $(n=1)$.

\section{Malignant tumors}

A total of 246 patients, 141 women (57\%) and 105 men (43\%), aged a mean of 53 years were included. Duration of the disease (time between the patients noticing the lesion and surgery) was a mean of 4 years (range, 1 month to 30 years). The location of the tumors is shown in - Table 2. Almost half of the le-
In two cases, excised tumors appeared to be malignancies. Both were fibrosarcoma: one mimicking (resembling) a ganglion cyst localized in the wrist, and one with a presentation similar to that of a cystic tumor on the dorsum of the hand. In both cases primary surgery was limited to excision of the lesion, but after diagnosis 
of the malignancies both patients underwent radicalization of the procedure (extended excision of the scar with oncological margins).

\section{Discussion}

Tumors of the hand and entire upper limb are frequent in hand surgeons' practice. Their presentation, diagnosis, and treatment may be different than for similar lesions affecting other parts of the body, mostly because of the complex anatomy and functional characteristics of the hand [1]. There is discrepancy in the literature regarding the incidence of soft tissue and bony tumors of the upper extremity. In a majority of the studies (including our own), soft tissue lesions had the highest incidence, while some authors report enchondromas to be the most common [4]. This is probably a result of the different patient selection criteria used in the studies, i.e., a proportion of minor soft tissue lesions may be operated on in outpatient settings and thus not be recorded in clinical databases. Management of bone tumors almost always requires hospital admission

The most common pathology in our series was giant cell tumor of the tendon sheath. This finding is consistent with results reported in the literature [1-3]. Giant cell tumors of the tendon sheath usually present as slow-growing lesions localized mostly on the digits, adjacent to the interphalangeal joints (in our series more common on the dorsal side of the digits). In most cases they are asymptomatic, but in some patients they may cause mild pain and discomfort or may interfere with hand function. Histologically, giant cell tumor is composed of multinucleated giant cells, histiocytes, fibrotic material, and deposits of hemosiderin [1]. Except for soft tissue involvement, giant cell tumors are found in bones, with the most common location in the epiphyses $[1,2]$. Treatment of these tumors consists in local excision. The recurrence rate reported in the literature is relatively high (a mean of $15 \%$, range $4-40 \%$ ) and is mostly caused by incomplete excision of the tumor and by overlooking residual satellite nodules. Giant cell tumor of the tendon sheath is poorly encapsulated and fre-

Obere Extremität 2015 · 10:252-257 DOI 10.1007/s11678-015-0314-4

The Author(s) 2015. This article is published with open access at Springerlink.com

\section{A. Zyluk · A. Mazur}

\section{Statistical and histological analysis of tumors of the upper extremity}

\section{Abstract}

Background. Tumors of the upper extremity are common and usually benign. The most commonly diagnosed are ganglion cysts: specific, non-neoplastic swellings localized mostly around the wrist.

Objective. The objective of this retrospective study was to determine the proportion of various types of nonganglionic hand tumors operated on at the authors' institution in 2014.

Methods. A total of 246 patients, 141 women $(57 \%)$ and 105 men (43\%), with a mean age of 53 years and with tumorsof the upper extremity, were identified and treated in the authors' institution in 2014.

Results. Almost half of the lesions were localized in the fingers $(n=119,48 \%)$, followed by the wrist ( $n=49,20 \%)$, metacarpus $(n=40$, $16 \%)$, and more proximal parts ( $n=38,16 \%)$.
The time between the patients noticing the lesion and surgery was a mean of 4 years (range, 1 month to 30 years). The most common lesion was giant cell tumor of the tendon sheath $(n=58,23 \%)$, followed by lipoma ( $n=40,16 \%)$, epidermal cyst $(n=23,9 \%)$, enchondroma $(n=16,6 \%)$, hemangioma ( $n=14,6 \%)$, fibroma $(n=11,(4 \%)$, glomus tumor $(n=10,(4 \%)$, and rheumatoid nodule $(n=10,(4 \%)$. Two cases of malignant fibrosarcoma were identified incidentally. Conclusion. A brief review of the literature is made referring to the data presented here.

\section{Keywords}

Upper extremity benign tumors · Benign soft tissue tumors · Surgical management . Statistics · Histology

\section{Statistische und histologische Analyse von Tumoren der oberen Extremität}

\section{Zusammenfassung}

Hintergrund. Tumoren der oberen Extremität sind häufig und meistens gutartig. Die häufigsten Diagnosen betreffen Ganglionzysten: typische, nichtneoplastische Schwellungen, die zumeist im Bereich des Handgelenks lokalisiert sind.

Ziel. Ziel der vorliegenden retrospektiven Studie war es, den Anteil der verschiedenen Typen von Handtumoren zu ermitteln, die keine Ganglionzyste darstellen und 2014 an der Klinik der Autoren operativ versorgt wurden.

Methoden. Insgesamt wurden 246 Patienten, 141 Frauen (57\%) und 105 Männer (43\%), mit einem Durchschnittsalter von 53 Jahren und Tumoren der oberen Extremität erfasst und 2014 in der Klinik der Autoren behandelt.

Ergebnisse. Fast die Hälfte der Läsionen waren an den Fingern lokalisiert $(n=119 ; 48 \%)$, es folgten das Handgelenk ( $n=49 ; 20 \%$ ), die Mittelhand $(n=40 ; 16 \%)$ und weiter proxi- mal gelegene Körperteile $(n=38 ; 16 \%)$. Die Zeitdauer zwischen Bemerkung der Veränderung durch den Patienten und der Operation betrug im Mittel 4 Jahre (Spannbreite: 1 Monat bis 30 Jahre). Die häufigste Veränderung war ein Riesenzelltumor der Sehnenscheide ( $n=58 ; 23 \%)$, es folgten Lipome $(n=40 ; 16 \%)$, epidermale Zysten $(n=23$; $9 \%)$, Enchondrome ( $n=16 ; 6 \%)$, Hämangiome $(n=14 ; 6 \%)$, Fibrome $(n=11 ;(4 \%)$, Glomustumoren $(n=10 ; 4 \%)$ und Rheumaknoten $(n=10 ; 4 \%)$. Als Zufallsbefund ergaben sich 2 Fälle eines malignen Fibrosarkoms. Schlussfolgerung. Abschließend wird eine kurze Übersicht über die Literatur zu den hier vorgestellten Daten gegeben.

\section{Schlüsselwörter}

Benigne Tumoren der oberen Extremität . Benigne Weichteiltumoren · Chirurgische Versorgung $\cdot$ Statistik $\cdot$ Histologie quently involves adjacent bones, joints, or tendons, which makes the radical excision difficult to perform. Satellite nodules are also relatively common.

Lipomas were the second commonest pathologies in our series. These tumors have no typical location and may be found anywhere in the upper extremity. In our series they were more frequently seen in the forearm and arm than in the hand or wrist ( 29 vs. 11 cases). Lipomas typically presented as soft, mobile, and painless masses, relatively easy to diagnose correctly before operation. They are mostly 


\begin{tabular}{lll}
\hline Table 3 Incidence of tumors identified in the study of 246 patients & \\
\hline Tumor type & Number of cases & $\%$ \\
\hline Giant cell tumor of the tendon sheath & 58 & 23 \\
\hline Lipoma & 40 & 16 \\
\hline Epidermoid cyst & 23 & 9 \\
\hline Enchondroma & 16 & 6 \\
\hline Hemangioma & 14 & 6 \\
\hline Glomus tumor & 11 & 4 \\
\hline Fibroma & 10 & 4 \\
\hline Rheumatoid nodule & 10 & 4 \\
\hline Schwannoma & 7 & 2.8 \\
\hline Gout nodule & 7 & 2.8 \\
\hline Wart (seborrheic) & 6 & 2.4 \\
\hline Glomangioma & 6 & 2.4 \\
\hline Keratopapilloma & 6 & 2.4 \\
\hline Granuloma telangiectasia & 5 & 2 \\
\hline Synovitis & 5 & 2 \\
\hline Neurofibroma & 4 & 1.6 \\
\hline Organized thrombus & 4 & 1.6 \\
\hline Vascular malformation & 3 & 1.2 \\
\hline Malignant tumors & 2 & 0.8 \\
\hline Other (single) & 9 & 3.6 \\
\hline Total & 246 & 100 \\
\hline & & \\
\hline
\end{tabular}

bone graft or synthetic substances (polymethylmethacrylate, calcium phosphate bone cement). In our series, half of the patients underwent curettage alone, whereas the second half received cancellous bone graft harvested from the distal radius. Pathologic fractures underwent primary treatment (conservative or operative with K-wire pinning) and tumor curettage was delayed until the fracture healed. This schedule is consistent with the literature reports showing a higher rate of complications in patients undergoing tumor excision before fracture consolidation $[7,8]$. Malignant transformation of enchondromas is uncommon, except of multiple endochondromatosis as in the case of Ollier disease and Maffucci syndrome.

Hemangiomas were the fifth most frequent tumor type in our series. They are more common in children, but are also seen in young adults, as was the case in our sample (mean age of patients, 22 years; range, 18-31 years). Hemangioma typically presented as a soft, reddishcyanotic mass, painless in most cases. It occurred mostly on the palmar surface of the digits (in 8 of 14 cases). In two patients the lesion was deeply localized in the forearm muscles, causing pain and swelling of the forearm. The diagnosis in these cases (cavernous hemangioma) was made based on magnetic resonance imaging studies. Treatment of hemangiomas consists in surgical excision, sometimes by coverage of the defect with skin graft or local flap. The operation may be technically demanding and precautions should be taken to avoid vascular compromising of the digits. Cavernous hemangiomas localized deeply in the muscles are also difficult to remove, as they may be extensive and infiltrate muscles without a distinct margin between normal and pathological tissue (- Figs. 4 and 5 ).

Glomus tumors were also diagnosed in our series (- Fig. 6). Glomus tumor is a benign hamartoma arising from a neuromyoarterial structure called a glomus body, which controls blood pressure and temperature. This lesion can be located anywhere, but the subungual region of the distal phalanx is particularly frequent, as occurred in all our cases. Glomus tumor presents as a tender part of the nail, and the painful area (or point) can be precise- 


\section{Original Contribution}
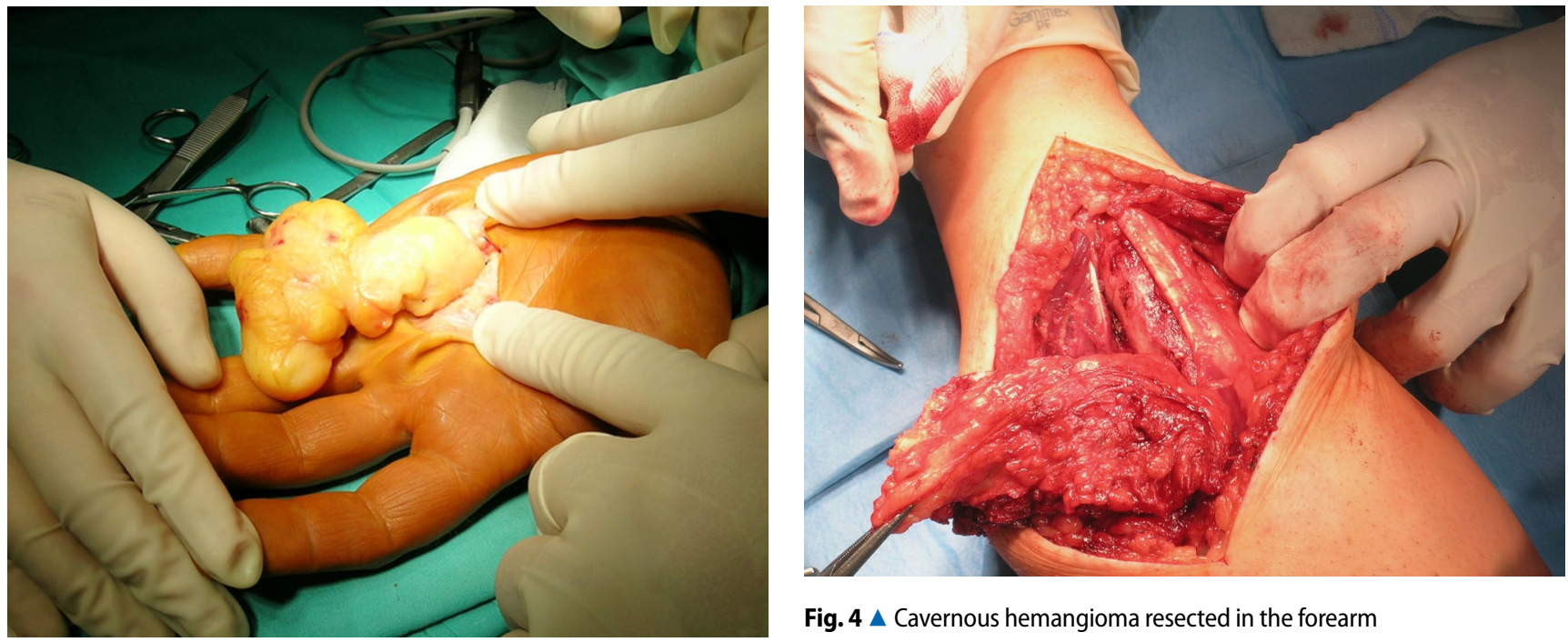

Fig. $4 \Delta$ Cavernous hemangioma resected in the forearm

Fig. $3 \Delta$ Retrieval of lipoma located deep in the hand
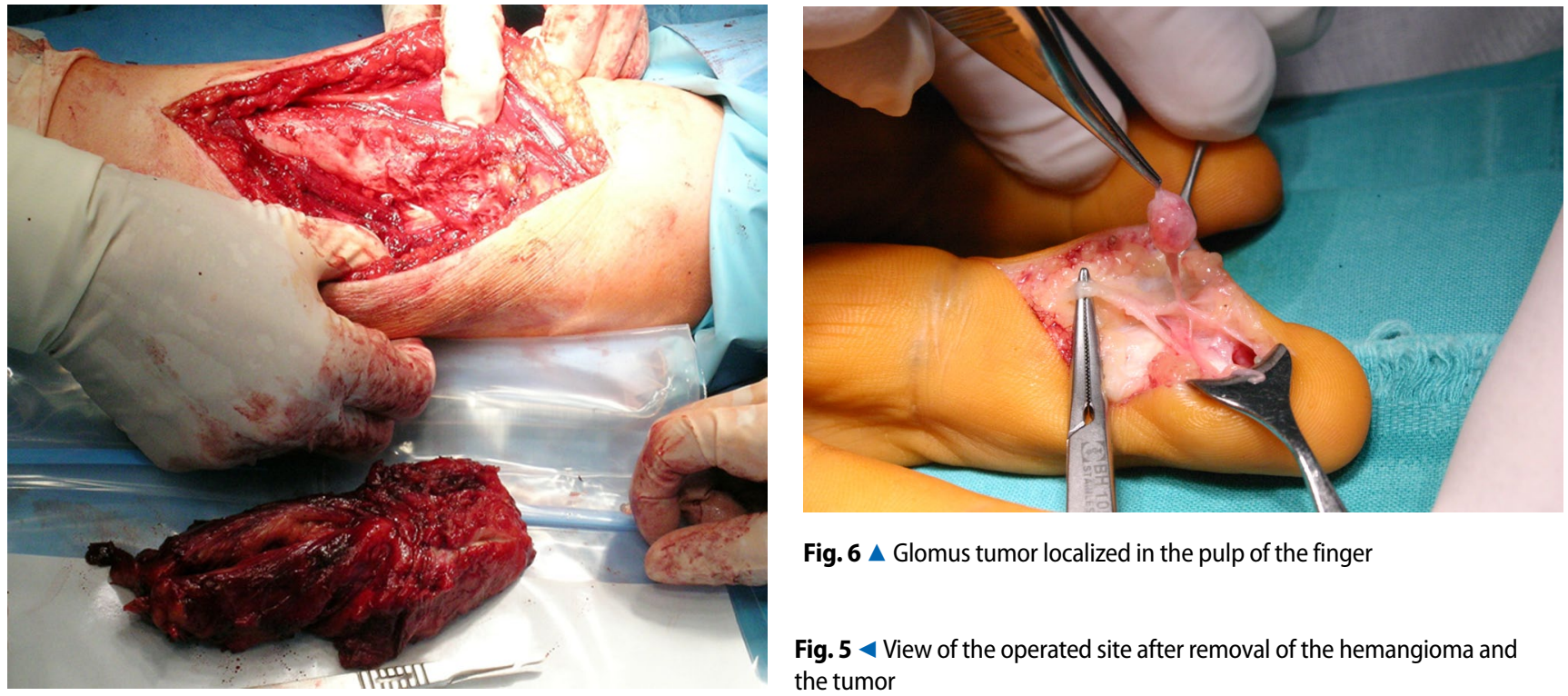

Fig. $6 \Delta$ Glomus tumor localized in the pulp of the finger

Fig. $5 \varangle$ View of the operated site after removal of the hemangioma and the tumor

ly determined by the patient. Local pain and tenderness are typically increased by exposure to cold. Radiographs may show erosion or a cavity of the bone of the distal phalanx, adjacent to the tumor. Nail plate deformity may also be seen. The diagnosis is relatively easy and surgical excision is usually curative with a low rate of recurrence $[2,9]$.

Other tumors were less common. Relatively interesting were nerve tumors, all of which were schwannomas $(n=7)$. Four of them were localized in the median nerve, two in the ulnar nerve on the forearm, and one arose from the digital nerve on the index finger. Five of these tumors were pre- operatively diagnosed as involving the nerve, but two were found incidentally during operation. In all cases, tumors were enucleated from the nerve without compromising nerve structure and function (• Figs. 7a, b, c, d, and e).

Two malignancies were diagnosed postoperatively among 246 excised tumors $(0.8 \%)$. In both cases, at presentation the lesion looked innocent and was considered benign. This finding confirms the necessity of a histological examination of most tumors after removal, except for typical-looking ganglia. Doubts may arise when treating patients with asymptomatic, slow-growing soft tissue tu- mors that are thought to be benign. We are fairy frequently faced with this problem in our ambulatory practice. Most of these patients do not wish to have surgery and observation is one of the accepted options in these cases. Additional imaging (i.e., ultrasonography or magnetic resonance imaging) may make the diagnosis more accurate, but is associated with higher costs and is never $100 \%$ reliable. Excisional biopsy of a tumor in the finger or wrist does not differ from its definitive removal, and is not recommended in small lesions. Sluijmer et al. suggested that the hand surgeon's preoperative diagnosis without imaging is usually correct 

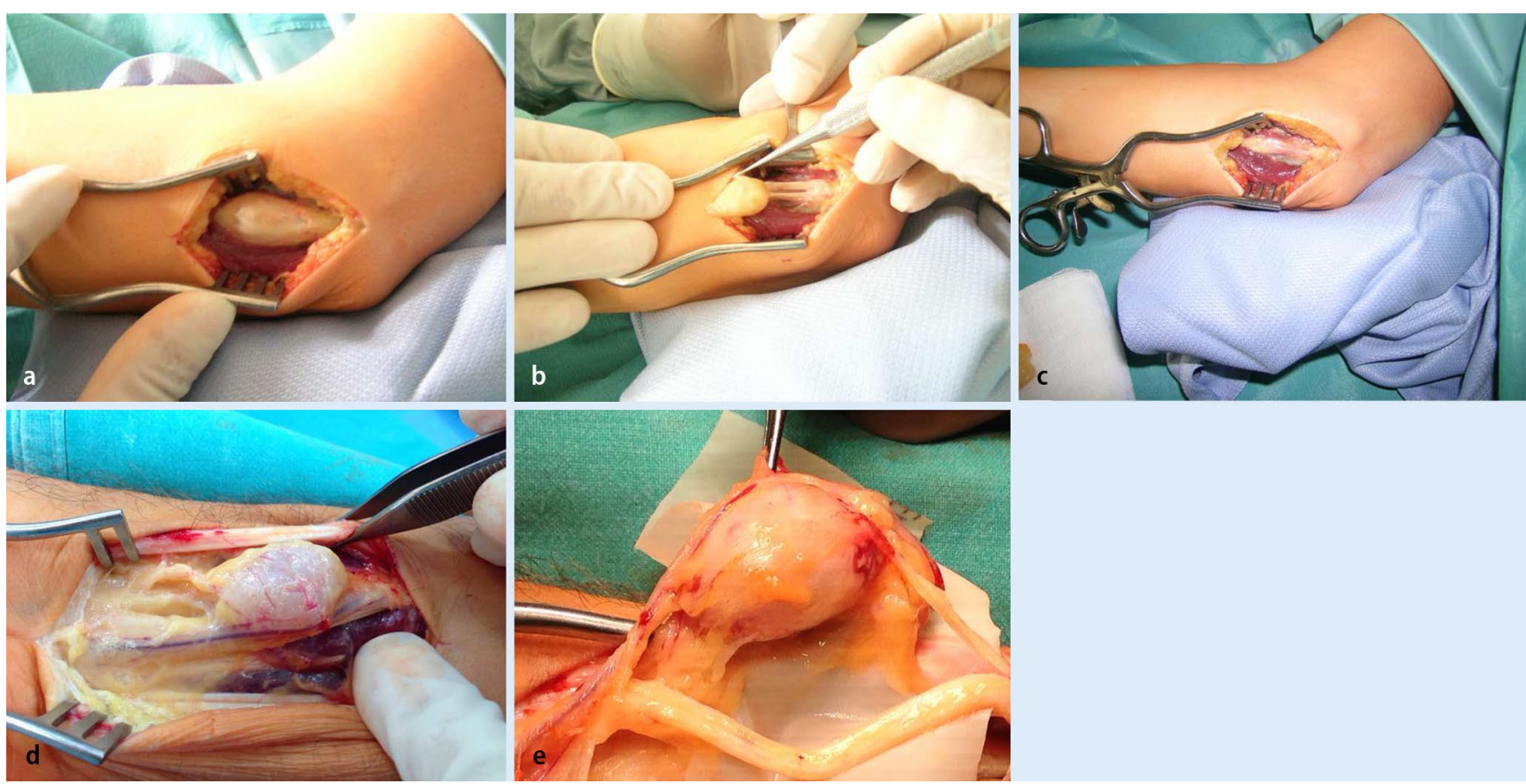

Fig. $7 \Delta$ a Schwannoma of the ulnar nerve found incidentally in a patient operated on for cubital tunnel syndrome. b Enucleation of the tumor from the ulnar nerve. $\mathbf{c}$ View of the nerve after removal of the tumor. $\mathbf{d}$, e Schwannoma of the median nerve

prior to excision of a mass in the hand. Discrepant diagnoses are usually benign and do not alter treatment [3]. These findings support observation as a reasonable option in innocent-looking, slow-growing tumors of the hand; however, this approach is not commonly accepted.

\section{Corresponding address}

\section{Prof. A. Zyluk MD}

Department of General and Hand Surgery Pomeranian Medical University in Szczecin ul. Unii Lubelskiej 1, 71-252 Szczecin azyluk@hotmail.com

\section{Compliance with ethical guidelines}

Conflict of interest. A. Zyluk and A. Mazur state that there are no conflicts of interest.

All studies on humans described in the present manuscript were carried out with the approval of the responsible ethics committee and in accordance with national law and the Helsinki Declaration of 1975 (in its current, revised form). Informed consent was obtained from all patients included in studies.

Open Access. This article is distributed under the terms of the Creative Commons Attribution License which permits any use, distribution, and reproduction in any medium, provided the original author(s) and the source are credited.

\section{References}

1. Di Grazia S, Succi G, Fragetta F, Perrotta RE (2013) Giant cell tumor of tendon sheath: study of 64 cases and review of literature. G Chir 34:149-152

2. Henderson MM, Neumeister MW, Bueno RA Jr (2014) Hand tumors: I. skin and soft-tissue tumors of the hand. Plast Reconstr Surg 133:154e-164e

3. Sluijmer HC, Becker SJ, Bossen JK, Ring D (2014) Excisional biopsy of suspected benign soft tissue tumors of the upper extremity: correlation between preoperative diagnosis and actual pathology. Hand (NY) 9:351-355

4. Martínez-Villén G, Badiola J, Alvarez-Alegret R, Mayayo $E$ (2014) Nerve compression syndromes of the hand and forearm associated with tumours of non-neural origin and tumour-like lesions. J Plast Reconstr Aesthet Surg 67:828-836

5. Simon MJ, Pogoda P, Hövelborn F, Krause M, Zustin J, Amling M, Barvencik F (2014) Incidence, histopathologic analysis and distribution of tumours of the hand. BMC Musculoskelet Disord 15:182. doi:10.1186/1471-2474-15-182

6. Farzan $\mathrm{M}$, Ahangar $\mathrm{P}$, Mazoochy $\mathrm{H}$, Ardakani MV (2013) Osseous tumours of the hand: a review of 99 cases in 20 years. Arch Bone Jt Surg 1:68-73

7. Henderson M, Neumeister MW, Bueno RA Jr (2014) Hand tumors: II. Benign and malignant bone tumors of the hand. Plast Reconstr Surg 133:814e$821 \mathrm{e}$

8. Ablove RH, Moy OJ, Peimer CA, Wheeler DR (2000) Early versus delayed treatment of enchondroma. Am J Orthop 29:771-778

9. Tang CY, Tipoe T, Fung B (2013) Where is the lesion? Glomus tumours of the hand. Arch Plast Surg 40:492-495 